\title{
Response of sunflower to organic and chemical fertilizers in different drought stress conditions
}

\author{
Aydin KHODAEI-JOGHAN ${ }^{1}$, Majid GHOLAMHOSEINI ${ }^{2}$, Majid AGHA-ALIKHANI ${ }^{3}$, Farhad HABIBZADEH ${ }^{4}$, \\ Ali SOROOSHZADEH ${ }^{5}$, Amir GHALAVAND ${ }^{6^{*}}$
}

Received July 06, 2017; accepted May 16, 2018.

Delo je prispelo 06. julija 2017, sprejeto 16. maja 2018.

\begin{abstract}
The main objectives of this research were to determine the effects of applying organic and chemical fertilizers under different irrigation regimes on sunflower (Helianthus annuus L.) morphological traits, yield components, grain yield and grain quality. The experiment was conducted as spilt plots based on a randomized complete block design with three replicates. Irrigation treatments at three levels (well-irrigated, mild and severe drought stress) were allocated to main plots and eight fertilizer treatments (urea (F1), urea + composted cattle manure (F2), zeocompost (F3), vermicompost (F4), zeolite-amended chicken manure (Z-ACM) (F5), zeocompost + vermicompost (F6), zeocompost + Z-ACM (F7) and vermicompost $+\mathrm{Z}$-ACM (F8)) were randomized in sub-plots. The results showed that irrespective of the drought stress intensity, organic fertilizer treatments produced more dry matter, heavier and greater grain than did chemical treatments. In well-irrigated plots, the highest grain yield was obtained from F6, F7 and F8 treatments. Under drought stress conditions, the highest grain yield was obtained from the high zeolite content organic fertilizers i.e. F3, F5 and F7. We concluded that amending soil with organic fertilizers in combination with zeolite can be a beneficial approach for decreasing chemical fertilizer application rates and improving the sustainability of agricultural systems.
\end{abstract}

Key words: drought stress; zeolite; soil fertility; grain quality; sunflower

\section{IZVLEČEK}

\section{ODZIV SONČNICE NA ORGANSKA IN MINERALNA GNOJILA V RAZMERAH RAZLIČNEGA SUŠNEGA STRESA}

\begin{abstract}
Glavni namen te raziskave je bil določiti učinke uporabe organskih in mineralnih gnojil $\mathrm{v}$ različnih režimih namakanja na morfološke lastnosti, komponente pridelka, pridelek zrnja in njegovo kakovost pri sončnici (Helianthus annuus L.). Izveden je bil poskus $\mathrm{z}$ deljenkami kot popolni naključni bločni poskus s tremi ponovitvami. Obravnavanja so obsegala namakanje na treh ravneh na glavnih ploskvah (dobro namakano, blagi in veliki sušni stres) in osem načinov gnojenja na podploskvah (urea (F1), urea + kompostiran goveji gnoj (F2), zeokompost (F3), vermikompost (F4), zeolite $\mathrm{z}$ dodatkom kokošjega gnoja (Z-ACM) (F5), zeokompost + vermikompost (F6), zeokompost + Z-ACM (F7) in vermikompost + Z-ACM (F8). Izsledki so pokazali, da je ne glede na jakost sušnega stresa obravnavanje $z$ organskimi gnojili dalo več suhe snovi, težja in večja zrna kot gnojenje z mineralnimi gnojili. Na dobro namakanih ploskvah je bil dosežen največji pridelek zrnja pri obravnavanjih F6, F7 in F8. $\mathrm{V}$ razmerah sušnega stresa je bil dosežen največji pridelek zrnja pri obravnavanjih, kjer so organska gnojila vsebovala veliko zeolita, obravnavanja F3, F5 in F7. Zaključili smo, da je dodadajanje organskih gnojil $\mathrm{z}$ zeolitom primeren pristop $\mathrm{k}$ zmanjševanju uporabe mineralnih gnojil pri izboljševanju trajnosti agroekosistemov.
\end{abstract}

Ključne besede: sušni stres; zeolite; rodovitnost tal; kvaliteta zrnja; sončnica

\footnotetext{
1 Assistant Professor of Plant Production and Genetics Department, Agriculture Faculty, Khuzestan Agricultural Sciences and Natural Resources University, Khuzestan, Iran

2 Assistant Professor of Oil seed Crops Department, Seed and Plant Improvement Institute. Agricultural Research, Education and Extension Organization (AREEO), Karaj, Iran

3 Associate Professor of Agronomy Department, Agriculture Faculty, Tarbiat Modares University, Tehran, Iran

4 Assistant Professor, Department of Plant Production and Breeding, Faculty of Agriculture and Natural Resources, Imam Khomeini International University, Qazvin, Iran

5 Associate Professor of Agronomy Department, Agriculture Faculty, Tarbiat Modares University, Tehran, Iran

6 Professor of Agronomy Department, Agriculture Faculty, Tarbiat Modares University, Tehran, Iran; *Corresponding author: ghalavand_amir@yahoo.com
} 


\section{INTRODUCTION}

Water and nutrients availability and their interactions commonly impact crop growth and yield (Jing et al., 2012). The impact of industrial farming practices on soil and water quality is now a global concern, and much recent research has focused on management options for reducing nutrient waste, improving soil quality and increasing crop yield (Edmeades, 2003). Alternative management systems, such as organic and integrated farming, are being promoted because they are more environmentally benign and enhance soil and water quality relative to industrial farming practices (Delate $\&$ Cambardella, 2004; Gholamhoseini et al., 2013). Nitrogen is one of the most important elements, playing a key role in achieving desired yield and quality of crop production. In sustainable agroecosystems, $\mathrm{N}$ cycle is sustainably managed to reduce the risk of $\mathrm{N}$ leaching to groundwater (Basso \& Ritchie, 2005). Therefore choosing the right amount of the most suitable $\mathrm{N}$ fertilizer source is critical to plant growth as well as livestock, human and environmental health.

Historically, organic materials such as manure have been mixed with soil to improve water and nutrient retention (Bigelow et al., 2004). Organic matter affects crop growth and yield directly by supplying nutrients and indirectly by modifying soil physical properties that can improve the root environment and stimulate plant growth (Bandyopadhyay et al., 2010). Vermicompost is a product of biodegradation of organic materials using various species of earthworms and microorganisms (Yang et al., 2015). Vermicomposts are rich in all essential plant nutrients, humic acids and vitamins as well as enzymes and plant growth regulators (Singh et al., 2011). Applications of vermicompost individually or in combination with either other organic fertilizers or mineral fertilizers have been proved effective to improve growth and yield of various crops (Javaad \&
Panwar, 2013; Singh et al., 2011; Simsek-Ersahin, 2011).

Zeocompost is made by composting cattle manure mixed with zeolite. Zeolites are crystalline, hydrated aluminosilicates, characterized by an ability to lose and gain water reversibly and to exchange their constituent elements without a major change of structure (Leggo et al., 2006; Gholamhoseini et al., 2012). Zeolites have high cation exchange capacity (200-300 $\mathrm{cmol}_{\mathrm{c}} \mathrm{kg}^{-1}$ ), selective absorption and structure stability over the long term (Baerlocher et al., 2001). Although the effects of various organic fertilizations have been studied in several crops (Yolcu, 2010; Rokhzadi \& Toashih, 2011), there is little information regarding the effect of zeolite and composted cattle manure on sunflower production.

Chicken manure is the organic waste from poultry composed of mainly feces and urine of chickens and spilled feed and feathers. The mixture of chicken manure with zeolite as bedding materials is referred as zeolite-amended chicken manure (Z-ACM). Therefore $\mathrm{Z}-\mathrm{ACM}$ is organic manure enriched with many major plant nutrients like $\mathrm{N}, \mathrm{P}, \mathrm{K}$ and many trace elements like $\mathrm{Zn}, \mathrm{Cu}$, As etc. In a study, Leggo (2000) investigated the response of wheat to chicken manure amended by zeolite and found out that crop faced a better growth rate when zeolite was applied in chicken manure, and reported that the increase of growth and yield is due to $\mathrm{N}$ availability by zeolite.

Considering the significant role of organic fertilizers in providing $\mathrm{N}$ in sustainable production of oil seed crops, an experiment was conducted to study the effect of different organic fertilizers on growth, grain yield, oil and protein content of sunflower grown under different drought stress conditions.

\section{MATERIALS AND METHODS}

The field experiment was conducted at Agricultural Research Farm, Faculty of Agriculture, Tarbiat Modares University, Tehran, Iran in 2012. The experiment was laid out as split plot in a randomized complete block design with three replicates. Irrigation treatments at three levels (irrigation after depleting 30, 50 and $70 \%$ of field capacity as well-irrigated (I1), mild drought stress (I2) and severe drought stress (I3), respectively) were allocated to main plots and eight fertilizer treatments (urea $(\mathrm{F} 1)$, urea + composted cattle manure (F2), zeocompost (F3), vermicompost (F4), Z-ACM (F5), zeocompost + vermicompost (F6), zeocompost +
Z-ACM (F7) and vermicompost + Z-ACM (F8)) were randomized in sub-plots. Soil samples were collected before fertilizer application at $0-30 \mathrm{~cm}$ depth to assess soil physical and chemical properties. Soil analyses were conducted using procedures described by soil and plant analysis council (1999). The soil texture was sandy loam based on the textural triangle classification (Table 1). Potassium and $\mathrm{P}$ were not applied during the growth season because the soil had adequate levels of these elements (Table 1). The values of moisture contents at field capacity, permanent wilting point and available water were 21.9 and $12 \%$, respectively. Time 
domain reflectometry (TDR model Trime-FM) was used to measure soil volumetric water at a soil depth of 0-60 $\mathrm{cm}$ (two soil layers, at $30 \mathrm{~cm}$ intervals). The following

$$
\operatorname{MAD}(\%)=100 \times \frac{1}{\mathrm{n}} \sum \frac{\mathrm{FCi}-\Theta \mathrm{i}}{\mathrm{FCi}-\mathrm{PWP}}
$$

Where MAD: management allowed depletion; $\mathrm{n}$ : number of soil layers at the depth of root development; FCi: field capacity at i layer; $\theta \mathrm{i}$ : soil water volumetric percentage before irrigation at $\mathrm{i}$ layer and PWP: permanent wilting point.

$$
\mathrm{Vd}=\frac{\mathrm{MAD}(\%) \times(\mathrm{FC}-\mathrm{PWP}) \times \mathrm{Rz} \times \mathrm{A}}{100}
$$

Where Vd: required water $\left(\mathrm{m}^{3}\right)$; MAD: management allowed depletion (\%); Rz: depth of root development (m); A: plot area $\left(\mathrm{m}^{2}\right)$ equation was used to calculate management allowed depletion (MAD) or maximum water depletion percentage (Allen et al., 1998).
Required water for each plot was calculated according to the following equation (Allen et al., 1998).

\begin{tabular}{|c|c|c|c|c|c|c|c|c|}
\hline \multirow[t]{2}{*}{$\begin{array}{l}\text { Soil depth } \\
\quad(\mathrm{cm})\end{array}$} & \multirow[t]{2}{*}{ soil texture } & \multirow[t]{2}{*}{$\mathrm{pH}\left(\mathrm{CaCl}_{2}\right)$} & \multirow[t]{2}{*}{$\begin{array}{c}\mathrm{EC} \\
\left(\mathrm{dS} \mathrm{\textrm {m } ^ { - 1 }}\right)\end{array}$} & \multirow[t]{2}{*}{$\begin{array}{l}\mathrm{C}_{\mathrm{org}} \\
(\%)\end{array}$} & \multirow[t]{2}{*}{$\begin{array}{c}\mathrm{N}_{\mathrm{t}} \\
(\%)\end{array}$} & \multirow[t]{2}{*}{$\begin{array}{l}\mathrm{N}_{\mathrm{av}} \\
(\%)\end{array}$} & $\mathrm{P}$ & K \\
\hline & & & & & & & \multicolumn{2}{|c|}{$\left(\mathrm{mg} \mathrm{kg}^{-1}\right)$} \\
\hline $0-30$ & sandy-loam & 7.6 & 2.28 & 1.01 & 0.09 & 0.001 & 24 & 375 \\
\hline
\end{tabular}

Table 1: Soil physiochemical properties*

A polyethylene pipeline and a counter were installed to control irrigation. According to sunflower $\mathrm{N}$ requirement $\left(120 \mathrm{~kg} \mathrm{~N} \mathrm{ha}^{-1}\right)$ and soil available $\mathrm{N}$ content $(\sim 0$, Table 1), required $\mathrm{N}$ was calculated. The $\mathrm{N}$ quantity to supply crop needs from organic fertilizers was calculated as follow (Sabahi, 2007).

Vermicompost, zeocompost and Z-ACM were supplied from Tehran University Horticultural Research Centre. Chemical analysis of the organic fertilizers is shown in table 2. After preparing the plots $(3 \mathrm{~m}$ width and $4 \mathrm{~m}$ length consisted of 6 rows) certain amount of organic fertilizers (Table 3) were spread onto the plots and then incorporated into the soil with shovel. There were $2 \mathrm{~m}$ gaps between the blocks, and a $1 \mathrm{~m}$ alley was established between each plot to prevent lateral water movement and other interferences. Sunflower seeds ('Azargol', Seed and Plant Improvement institute, Karaj, Iran) were sown by hand at depths of $5 \mathrm{~cm}$ on the rows $25 \mathrm{~cm}$ apart. At first, the experimental plots were over-seeded and then thinned at the three-leaf stage to achieve the recommended plant density of 80,000 plants $\mathrm{ha}^{-1}$. The first irrigation was performed immediately after sowing. Weeds were controlled manually during growing season. The crop was harvested at physiological maturity by cutting the plants off at ground level.

The plants were analyzed into laboratory, being determined the following traits: plant height, stem diameter, dry matter and grain yield as well as yield components including head diameter, number of grains per head and 1000-grain mass. Final yield was calculated as the grain yield at $10 \%$ moisture content and expressed in $\mathrm{kg} \mathrm{ha}^{-1}$. Harvest index was calculated as the ratio of grain yield to above ground biomass yield expressed as a percentage. Grain oil and protein percentage were determined using Inframatic (Inframatic 8620 Percor) and Kjeldahl methods, respectively. The data were subjected to analysis of variance (ANOVA), to determine the variability of each measurement. The means of treatment were compared according to Fisher's LSD (0.05). 
Aydin KHODAEI-JOGHAN et al.

Table 2: Organic fertilizers chemical properties

\begin{tabular}{|c|c|c|c|c|}
\hline Characteristics & Zeocompost & Z-ACM & Vermicompost & composted cattle manure \\
\hline $\mathrm{N}(\%)$ & 1.25 & 4.2 & 1.4 & 1.1 \\
\hline Available nitrogen $(\%)^{*}$ & 0.85 & 2 & 0.75 & 0.85 \\
\hline $\mathrm{P}(\%)$ & 0.39 & 1.2 & 0.5 & 0.6 \\
\hline $\mathrm{K}(\%)$ & 1.7 & 0.8 & 0.7 & 2.4 \\
\hline Organic carbon $(\%)$ & 20.2 & --- & 9.6 & 25.4 \\
\hline $\mathrm{pH}$ & 5.8 & 9.7 & 2.7 & 9.1 \\
\hline $\mathrm{EC}\left(\mathrm{ds} \mathrm{m^{-1 } )}\right.$ & 8.14 & --- & 8.2 & 21.4 \\
\hline $\mathrm{Cu}\left(\mathrm{mg} \mathrm{kg}^{-1}\right)$ & 7.26 & 35.9 & 80.8 & 21.2 \\
\hline $\mathrm{Zn}\left(\mathrm{mg} \mathrm{kg}^{-1}\right)$ & 101.4 & 110.8 & 16.7 & 117 \\
\hline $\mathrm{Fe}\left(\mathrm{mg} \mathrm{kg}^{-1}\right)$ & 1245 & 550 & 89.1 & 6525 \\
\hline $\operatorname{Mn}\left(\mathrm{mg} \mathrm{kg}^{-1}\right)$ & 237 & 430 & 620 & 289 \\
\hline
\end{tabular}

$*$ Available nitrogen $=95 \%$ of $\mathrm{NH}_{4}{ }^{+}+25 \%$ of organic $\mathrm{N}$ (Tarkalson et al., 2006)

Table 3: Amount of applied fertilizers to supply $120 \mathrm{~kg} \mathrm{~N}$ ha $^{-1}$

\begin{tabular}{ccccccc}
\hline Treatments & $\begin{array}{c}\text { urea } \\
\left(\mathrm{kg} \mathrm{ha}^{-1}\right)\end{array}$ & $\begin{array}{c}\text { composted cattle manure } \\
\left(\mathrm{t} \mathrm{ha}^{-1}\right)\end{array}$ & $\begin{array}{c}\text { Zeocompost } \\
\left(\mathrm{t} \mathrm{ha}^{-1}\right)\end{array}$ & $\begin{array}{c}\text { Z-ACM } \\
\left(\mathrm{tha}^{-1}\right)\end{array}$ & $\begin{array}{c}\text { Vermicompost } \\
\left(\mathrm{tha}^{-1}\right)\end{array}$ & $\begin{array}{c}\text { Zeolite } \\
\left(\mathrm{kg} \mathrm{ha}^{-1}\right)\end{array}$ \\
\hline F1 & 261 & 0 & 0 & 0 & 0 & 0 \\
F2 & 70 & 7 & 0 & 0 & 0 & 0 \\
F3 & 0 & 0 & 14 & 0 & 0 & 2100 \\
F4 & 0 & 0 & 0 & 0 & 16 & 2400 \\
F5 & 0 & 0 & 0 & 6 & 0 & 900 \\
F6 & 0 & 0 & 7 & 0 & 8 & $1050+1200$ \\
F7 & 0 & 0 & 7 & 3 & 0 & $1050+450$ \\
F8 & 0 & 0 & 0 & 3 & 8 & $450+1200$ \\
\hline
\end{tabular}

\section{RESULTS AND DISCUSSION}

The results indicated that the main effects of irrigation and fertilizer treatments were significant on all studied traits except for harvest index (Table 4). In addition, dry matter yield, grain number per head and final grain yield as well as oil and protein percentage were significantly affected by interaction between irrigation and fertilizers treatments (Table 4).

\subsection{Dry matter yield}

Under well-irrigation conditions, increased $\mathrm{N}$ availability due to organic fertilizers application has led to increased vegetative growth and eventually increased dry matter production (Fig. 1). Among organic fertilizer treatments, zeocompost + vermicompost, zeocompost + Z-ACM and vermicompost + Z-ACM treatments caused the maximum dry matter yield, among which vermicompost + Z-ACM showed the maximum value of $6563 \mathrm{~kg} \mathrm{ha}^{-1}$ (Table 5). Increase in dry matter production may be due to enhanced soil $\mathrm{N}$ content on account of Z-ACM application during growing season and also improved soil microbial activity through applying vermicompost (Salehi et al., 2016). In drought stressed plots, organic fertilizers in which zeolite was applied led to increased dry matter (Fig. 1). Under drought stress conditions, the maximum dry matter yield was obtained from Z-ACM and zeocompost + Z-ACM treatments (Fig. 1). By contrast, the minimum yield was related to urea and urea + composted cattle manure treatments (Fig. 1). It has been reported that zeolite application improves soil water retention capacity (Xiubin \& Zhanbin, 2001; He et al., 2002). 


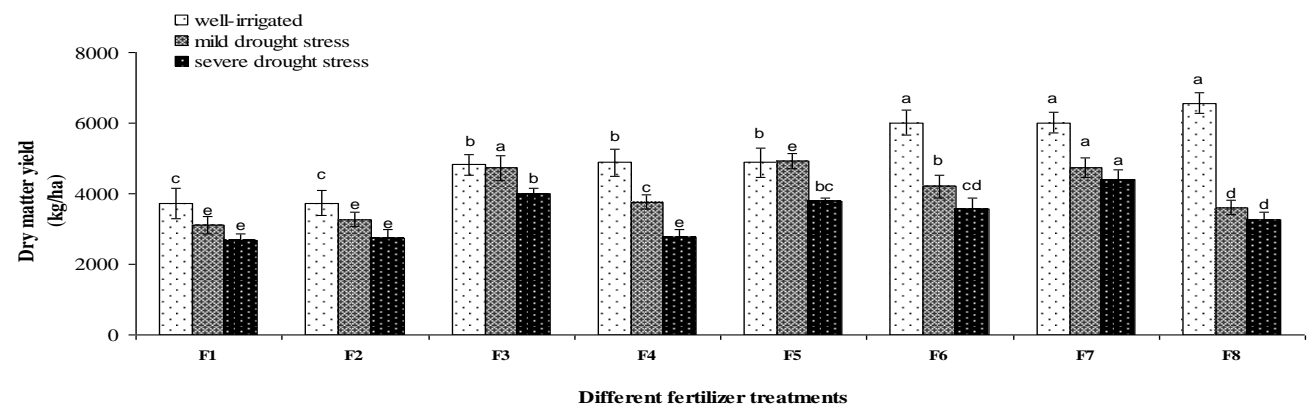

Figure 1: Interaction effect of irrigation treatments $\times$ fertilizer treatments on sunflower dry matter yield. In each irrigation treatments, means followed by the same letter are not significantly different $(P \leq 0.05)$. Vertical bars indicate standard deviation $(\mathrm{n}=3)$ 
Aydin KHODAEI-JOGHAN et al.

Table 4: Analysis of variance on yield, yield components, morphology and qualitative characteristics of sunflower as affected by irrigation regimes and fertilizers

\begin{tabular}{|c|c|c|c|c|c|c|c|c|c|c|c|}
\hline S.O.V & df & $\begin{array}{c}\text { Dry matter } \\
\text { yield }\end{array}$ & $\begin{array}{l}\text { Grain } \\
\text { yield }\end{array}$ & $\begin{array}{c}\text { Harvest } \\
\text { index }\end{array}$ & $\begin{array}{c}\text { Grain number } \\
\text { per head }\end{array}$ & $\begin{array}{c}1000 \text { grain } \\
\text { mass }\end{array}$ & $\begin{array}{l}\text { Plant } \\
\text { height }\end{array}$ & $\begin{array}{c}\text { Stem } \\
\text { diameter }\end{array}$ & $\begin{array}{c}\text { Head } \\
\text { diameter }\end{array}$ & $\begin{array}{c}\text { Grain oil } \\
\text { percentage }\end{array}$ & $\begin{array}{c}\text { Grain protein } \\
\text { percentage }\end{array}$ \\
\hline Replication & 2 & $\mathrm{~ns}$ & ns & ns & ns & ns & $\mathrm{ns}$ & $\mathrm{ns}$ & $* *$ & $* *$ & ns \\
\hline Irrigation & 2 & $* *$ & $* *$ & $\mathrm{~ns}$ & $* *$ & $* *$ & $* *$ & $* *$ & $* *$ & $* *$ & $* *$ \\
\hline Fertilizer & 7 & $* *$ & $* *$ & $\mathrm{~ns}$ & $*$ & $* *$ & $* *$ & $* *$ & $* *$ & $* *$ & $*$ \\
\hline Interaction & 14 & $* *$ & $* *$ & ns & $* *$ & ns & $\mathrm{ns}$ & $\mathrm{ns}$ & ns & $* *$ & $*$ \\
\hline Error & 42 & 147854.33 & 54126.67 & 52.61 & 553.34 & 6.64 & 224.83 & 1.54 & 8.52 & 2.36 & 3.07 \\
\hline C.V (\%) & & 9.20 & 13.30 & 17.00 & 5.70 & 5.00 & 11.23 & 6.00 & 13.30 & 3.50 & 8.10 \\
\hline
\end{tabular}

ns: non-significant, *: significant at 0.05 and $* *$ : significant at 0.01 probability level

Table 5: Main effects of irrigation regimes and fertilizers systems on sunflower yield and yield components

\begin{tabular}{|c|c|c|c|c|c|}
\hline Treatments & $\begin{array}{c}\text { Dry matter } \\
\left(\mathrm{kg} \mathrm{ha}^{-1}\right)\end{array}$ & $\begin{array}{l}\text { Grain yield } \\
\left(\mathrm{kg} \mathrm{ha}^{-1}\right)\end{array}$ & Harvest index (\%) & $\begin{array}{c}\text { Grain number per } \\
\text { head }\end{array}$ & $\begin{array}{c}1000 \text { grain } \\
\text { mass }(\mathrm{g})\end{array}$ \\
\hline \multicolumn{6}{|l|}{ Irrigation regimes } \\
\hline I1 & $5075 \mathrm{a}$ & $2084 \mathrm{a}$ & $41.8 \mathrm{a}$ & $516 \mathrm{a}$ & $57.3 \mathrm{a}$ \\
\hline $\mathrm{I} 3$ & $3397 \mathrm{c}$ & $1533 \mathrm{c}$ & $45.4 \mathrm{a}$ & $299 \mathrm{c}$ & $46.5 \mathrm{c}$ \\
\hline \multicolumn{6}{|l|}{ Fertilizers systems } \\
\hline F1 & $3176 \mathrm{~d}$ & $1342 \mathrm{~d}$ & $45.5 \mathrm{a}$ & $348 \mathrm{~d}$ & $45.8 \mathrm{c}$ \\
\hline $\mathrm{F} 2$ & $3245 \mathrm{~d}$ & $1332 \mathrm{~d}$ & $41.6 \mathrm{a}$ & $376 \mathrm{c}$ & $46.5 \mathrm{c}$ \\
\hline F3 & $4513 \mathrm{~b}$ & $1773 \mathrm{bc}$ & $39.7 \mathrm{a}$ & $422 \mathrm{~b}$ & $49.6 \mathrm{~b}$ \\
\hline $\mathrm{F} 4$ & $3805 \mathrm{c}$ & $1579 \mathrm{c}$ & $40.9 \mathrm{a}$ & $384 \mathrm{c}$ & $50.8 \mathrm{~b}$ \\
\hline F5 & $4527 \mathrm{~b}$ & $1967 \mathrm{ab}$ & $44.3 \mathrm{a}$ & $411 b$ & $51.3 \mathrm{~b}$ \\
\hline F6 & $4594 \mathrm{~b}$ & $1957 \mathrm{ab}$ & $43.0 \mathrm{a}$ & $412 b$ & $56.4 \mathrm{a}$ \\
\hline F7 & $5051 \mathrm{a}$ & $2141 \mathrm{a}$ & $42.6 \mathrm{a}$ & $472 \mathrm{a}$ & $54.8 \mathrm{a}$ \\
\hline $\mathrm{F} 8$ & $4466 \mathrm{~b}$ & $1909 \mathrm{~b}$ & $43.6 \mathrm{a}$ & $424 \mathrm{~b}$ & $57.0 \mathrm{a}$ \\
\hline
\end{tabular}

Means in columns followed by the same letters are not significantly different at $P \leq 0.05$ using LSD test.

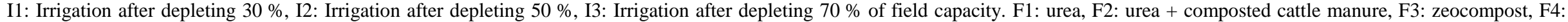
vermicompost, F5: Z-ACM, F6: zeocompost + vermicompost, F7: zeocompost + Z-ACM and F8: vermicompost + Z-ACM 


\subsection{Grain yield}

There was a significant difference among irrigation treatments in terms of grain yield (Table 5). The maximum grain yield $\left(2084 \mathrm{~kg} \mathrm{ha}^{-1}\right)$ was obtained from well irrigated plots. Grain yield decreased by 22 and $29 \%$ due to mild and severe drought stress, respectively (Table 5). Sunflower grain yield strongly depends on water availability in the soil and would decrease with increasing water shortage level (Sezen et al., 2011). The final grain yield reduction due to drought stress was mainly through low grain mass and grain number per head and also head diameter. In this study, there were positive and significant correlations between grain yield and yield components i.e. grain number per head, grain mass and head diameter. Drought stress, like other environmental stresses, reduces grain filling period through reducing photosynthesis and assimilates transport into the grains. The maximum grain yield was achieved when plants were well irrigated and treated with zeocompost + vermicompost, zeocompost + Z$\mathrm{ACM}$ or vermicompost $+\mathrm{Z}$-ACM treatments (Fig. 2). By contrast, the minimum grain yield was related to urea followed by urea + composted cattle manure treatments (Fig. 2). It seems that the application of organic fertilizers accompanied by zeolite in the present experiments decreased $\mathrm{N}$ leaching because organic fertilizers improved the physicochemical conditions of the soil (Gholamhoseini et al., 2013) and increased the activity and penetration of plant roots (Evanylo et al., 2008). In addition, the most important process by which zeolite application decreases $\mathrm{N}$ leaching arises from the unique properties of this natural mineral. In zeolites, the canals are so large that cations such as ammonium can fit therein, but bacteria, particularly nitrifying bacteria, cannot access the zeolite canals (Baerlocher et al., 2001). Therefore, when ammonium is available in organic fertilizers or soil, zeolite selectively absorbs ammonium (Gholamhoseini et al., 2012) and renders it unavailable to nitrifying bacteria, which are active in well-aerated sandy soils. Thus, the transformation of ammonium to nitrate (the latter of which is prone to leaching) will decrease with zeolite addition, therefore decreasing $\mathrm{N}$ leaching. Any change in $\mathrm{N}$ availability will have significant effect on grain yield as $\mathrm{N}$ availability during growing season affects assimilates allocation among vegetative and reproductive organs. Increase in grain yield on account of organic fertilizers application may be due to the role of composts in improving soil $\mathrm{N}$ content over growing season (Bandyopadhyay et al., 2010). As can be seen from table 2, Z-ACM is rich in $\mathrm{N}, \mathrm{P}$ and $\mathrm{K}$ as well as $\mathrm{Mg}$. Nitrogen is released quickly from Z-ACM during early growth stage (Sabahi, 2007) and help plants to establish rapidly and grow strong root systems. In the rest of the growth season, $\mathrm{N}$ is released gradually from vermicompost throughout the growth stages of the crop. On the other hands, it appears that increase of grain yield in organic treatments, especially F8, results from a proper balance between available soil $\mathrm{N}$ and plant $\mathrm{N}$ requirements. Under mild and severe drought stress conditions the maximum grain yield was obtained from those treatments in which more zeolite was applied i.e. zeocompost, Z-ACM and zeocompost + Z-ACM treatments. By contrast, the minimum grain yield was observed in chemical and combined treatments. Zeolite provides more moisture by improving soil water retention capacity and promotes sunflower grain yield. Generally, zeolite can decrease the bulk density and increase total porosity, which consequently increase soil water content (Nakhli et al., 2017). Its application changes the inter-particle porosity of soil. Zeolite is a porous medium with open pore network channels into its structure, which can also play an important role in water retention. Additionally, it seems that adding zeolite to organic fertilizers prevents the $\mathrm{N}$ loss from the soil due to absorption and subsequent release of the $\mathrm{N}$ by the zeolite. In this way, organic fertilizers amended by zeolite can act as a slow-release fertilizer to supply $\mathrm{N}$ to the crop gradually. A direct relationship between $\mathrm{N}$ supply and crop dry matter has been reported by Hermanson et al. (2000). Thus, it is to be expected that that organic fertilizers with zeolite (especially F6 and F8) will increase sunflower grain yield. 


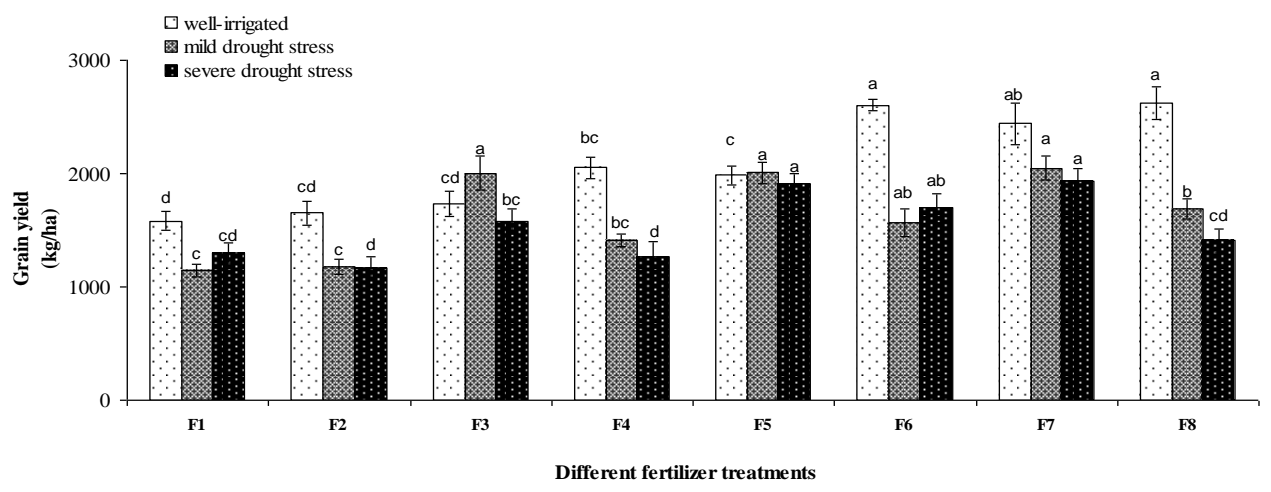

Figure 2: Interaction effect of irrigation treatments $\times$ fertilizer treatments on sunflower grain yield. In each irrigation treatments, means followed by the same letter are not significantly different $(P \leq 0.05)$. Vertical bars indicate standard deviation $(\mathrm{n}=3)$

\subsection{Harvest index}

The harvest index was not affected by irrigation regimes and fertilizer treatments (Table 4). According to Hay and Porter (2006) harvest index has been reported to have lower variances so that in some crops the value has reached to its maximum. In a nutshell, any factor that reduces the biological yield can lead to reduction in grain yield and finally will causes weaker variation in harvest index.

\subsection{Yield components}

According to the results application of combined organic fertilizers (zeocompost, vermicompost, zeocompost + Z-ACM and vermicompost + Z-ACM) under well irrigation conditions produced more grain per head compared with other treatments (Fig. 3). It appears that the availability of $\mathrm{N}$ and other nutrients supplied from composts improves photosynthesis and increases assimilate production during reproductive growth stage. Nitrogen and other nutrients are released gradually from organic fertilizers and nourish plants during growing season. Slow release reduces the risk of nutrients leaching into waterways and support plants until the end of growing season. Under mild and severe drought stress the maximum grain number per head were found in those treatments in which more zeolite was applied (zeocompost, Z-ACM and zeocompost + ZACM) (Fig. 3). Zeolites can modify soils water content by altering the bulk density and total and aeration porosity (Nakhli et al., 2017). Bulk density is a basic soil physical property that can have an effect on the total porosity and topsoil stability, such that the bulk density of light-textured soils can be lowered with the application of zeolites (Ramesh et al., 2011). Furthermore, in sandy soils, zeolites application can lead to higher water holding capacities, which can be attributed to zeolites high pore volumes that enable them to hold more water in their structures (Ramesh et al., 2011). Other researchers have also found water retention or soil water contents to be greater in soils to which zeolite was applied. Bigelow et al. (2001) mixed $10 \%$ zeolite with putting green sand and noted a $20 \%$ increase in volumetric water content during the first year after putting green establishment as compared with unamended sand. Al-Busaidi et al. (2008) applied zeolite to sand at a rate of $5 \mathrm{~kg} \mathrm{~m}^{-2}$ (5\% by mass), reporting an increase in soil water content of approximately $2.5 \%$ to $4.8 \%$ (by mass), depending on water source, as compared with a control. In addition, zeolites can modify the soil hydraulic conductivity, a physical property of soil showing the easiness of water movements within the soil, due to the existence of channels within their structure (Nakhli et al., 2017). In heavy-textured soils, zeolites are able to increase the hydraulic conductivity, while in light-textured soil, they lower the hydraulic conductivity (Razmi \& Sepaskhah, 2012). In a study clinoptilolite zeolite was added to four different soil textures including clay, loam, loamy sand, and sand. The results indicated that application of zeolite decreased the hydraulic conductivity of sandy and loamy soils. On the contrary, it increased the hydraulic conductivity of clay soil (Gholizadeh-Sarabi \& Sepaskhah, 2013). Change in the hydraulic conductivity was highly attributed to change the average particle size of the soil (Mahabadi et al., 2007). 


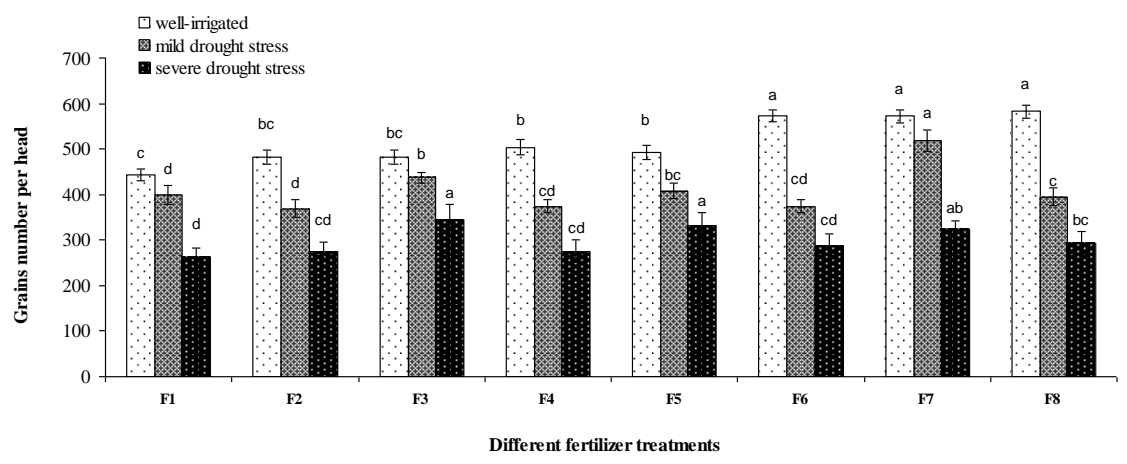

Figure 3: Interaction effect of irrigation treatments $\times$ fertilizer treatments on sunflower grain number per head. In each irrigation treatments, means followed by the same letter are not significantly different $(P \leq 0.05)$. Vertical bars indicate standard deviation $(\mathrm{n}=3)$

Grain mass as an important yield component was significantly affected by irrigation treatments (Table 4). The maximum and minimum grain mass were related to well irrigated and severe drought stress plots, respectively (Table 5). Shorter grain filling period due to water deficit stress is the main reason for decreased grain mass (D' Andria et al., 1995). Among fertilizer treatments, combined organic treatments and chemical treatments produced the maximum and minimum grain mass, respectively (Table 5). Increase in grain mass has been found to be correlated with increase in nutrients uptake (Efeoğlu et al., 2008). According to Hay and Porter (2006) consistent $\mathrm{N}$ availability increases dry matter production and leaf area duration. So it is not surprising that organic fertilizers play a major in increasing grain mass.

\subsection{Morphological characteristics}

Drought stress significantly reduced plant height so that there were 18 and $31 \%$ reduction when control treatment was compared with mild and severe drought stress treatments, respectively (Table 6). Reduction in plant height may be due to lower turgor pressure and diminished cell division on account of water deficit stress (Ogbonnaya et al., 2003). Similar results have been found by Kazi et al. (2002). From the results the tallest and shortest plants were observed when combined organic fertilizers (zeocompost + vermicompost, zeocompost $+\mathrm{Z}$-ACM and zeocompost $+\mathrm{Z}$-ACM) and combine chemical treatments (urea and urea + cattle manure) were applied, respectively (Table 6). Plant height is an index of vegetative growth. Considering this fact that $\mathrm{N}$ is constituent of proteins, $\mathrm{N}$ availability plays a key role in plant growth and cell expansion. The positive effect of $\mathrm{N}$ in stem elongation in sunflower has been reported by Khaligh and Cheema (2005). In addition, increase in plant height might be due to application of different organic fertilizers at the same time. For example, Z-ACM provides required $\mathrm{N}$ during early growth stages and vermicompost improves growth through increasing vitamins and plant growth regulators into the soil. On the other hands, the application of organic fertilizer improves soil physical and chemical properties and increases root activity, leading to enhancement of plant $\mathrm{N}$ absorption (Gholamhoseini et al., 2013).

Stem diameter decreased due to mild and severe drought stress (Table 6). Similar results have been reported by Kazi et al. (2002). Stem diameter was at the minimum limit when urea was applied (Table 6). From the other side, the maximum stem diameter was observed when vermicompost + Z-ACM treatment was used (Table 6). Nutrients availability in combined organic treatments improves photosynthesis and assimilates production which finally leads to more vegetative growth. Stem diameter affect yield and yield components so that plants with thicker stems produce more grain yield.

The results indicated that the maximum and minimum head diameters were related to well-irrigated and drought stressed plots (Table 6). Head diameter is not only controlled by environmental factors such as soil moisture, but also by genetic properties. Water availability during reproductive stage has critical role in increasing yield via increasing assimilates production and sink size such as grain size and head diameter (Tarantino \& Alba, 1979). According to the results application of combined organic fertilizers could increase head diameter (Table 6). 
Aydin KHODAEI-JOGHAN et al.

Table 6: Main effects of irrigation regimes and fertilizers systems on sunflower morphological and qualitative characteristics

\begin{tabular}{cccccc}
\hline Treatments & $\begin{array}{c}\text { Plant height } \\
(\mathrm{cm})\end{array}$ & $\begin{array}{c}\text { Stem diameter } \\
(\mathrm{mm})\end{array}$ & $\begin{array}{c}\text { Head diameter } \\
(\mathrm{cm})\end{array}$ & $\begin{array}{c}\text { Grain oil } \\
(\%)\end{array}$ & $\begin{array}{c}\text { Grain protein } \\
(\%)\end{array}$ \\
\hline Irrigation regimes & & & & & \\
\hline I1 & $159 \mathrm{a}$ & $23.5 \mathrm{a}$ & $24.4 \mathrm{a}$ & $45.7 \mathrm{a}$ & $19.6 \mathrm{c}$ \\
I2 & $130 \mathrm{~b}$ & $20.5 \mathrm{~b}$ & $21.9 \mathrm{~b}$ & $44.2 \mathrm{~b}$ & $21.6 \mathrm{~b}$ \\
I3 & $109 \mathrm{c}$ & $19.1 \mathrm{c}$ & $19.3 \mathrm{c}$ & $41.9 \mathrm{c}$ & $23.5 \mathrm{a}$ \\
\hline Fertilizers systems & & & & & \\
\hline F1 & $103 \mathrm{c}$ & $18.3 \mathrm{~d}$ & $19.2 \mathrm{c}$ & $42.3 \mathrm{de}$ & $22.1 \mathrm{~b}$ \\
F2 & $105 \mathrm{c}$ & $19.9 \mathrm{bc}$ & $19.8 \mathrm{c}$ & $41.9 \mathrm{e}$ & $23.2 \mathrm{a}$ \\
F3 & $124 \mathrm{~b}$ & $19.7 \mathrm{c}$ & $22.0 \mathrm{ab}$ & $44.3 \mathrm{bc}$ & $22.2 \mathrm{ab}$ \\
F4 & $127 \mathrm{~b}$ & $20.6 \mathrm{bc}$ & $21.1 \mathrm{bc}$ & $43.7 \mathrm{~cd}$ & $21.4 \mathrm{~b}$ \\
F5 & $129 \mathrm{~b}$ & $20.9 \mathrm{~b}$ & $21.3 \mathrm{ab}$ & $44.8 \mathrm{bc}$ & $21.2 \mathrm{bc}$ \\
F6 & $174 \mathrm{a}$ & $22.5 \mathrm{a}$ & $22.8 \mathrm{ab}$ & $43.6 \mathrm{~cd}$ & $19.6 \mathrm{c}$ \\
F7 & $137 \mathrm{a}$ & $23.0 \mathrm{a}$ & $24.5 \mathrm{a}$ & $45.3 \mathrm{ab}$ & $22.1 \mathrm{ab}$ \\
F8 & $164 \mathrm{a}$ & $23.4 \mathrm{a}$ & $22.7 \mathrm{ab}$ & $45.9 \mathrm{a}$ & $20.9 \mathrm{bc}$ \\
\hline
\end{tabular}

Means in columns followed by the same letters are not significantly different at $p<0.05$ using LSD test. I1: Irrigation after depleting $30 \%$, I2: Irrigation after depleting $50 \%$, I3: Irrigation after depleting $70 \%$ of filed capacity. F1: urea, F2: urea + composted cattle manure, F3: zeocompost, F4: vermicompost, F5: Z-ACM, F6: zeocompost + vermicompost, F7: zeocompost + Z-ACM and F8: vermicompost + Z-ACM

\subsection{Grain quality}

The maximum grain protein content was obtained from severe drought stress treatment, whereas the minimum value was found in well-irrigated plots (Fig. 4). It has been reported that higher temperature and lower soil moisture content during growing season decrease grain mass and oil percentage (Mirales, 1997). It has been reported that oil content would increase with increasing soil available water content (Wang et al., 2003). Reduction in oil percentage because of drought stress might be due to alterations in seeds metabolisms and/or assimilates transfer into the seeds. In fact, drought stress, especially at seed filling stage, reduces oil percentage but increases protein percentage. Under well-irrigation conditions, grain oil percentage was higher in plants which were treated with organic fertilizer containing vermicompost (vermicompost, vermicompost + zeocompost and vermicompost + Z$\mathrm{ACM}$ ) so that oil percentage in these treatments increased by 12,12 and $16 \%$, respectively, compared with chemical treatment (Fig. 5). From one side, slow release of $\mathrm{N}$ and other nutrients from vermicompost and from the other side improving soil physical properties by organic fertilizers could improve plant growth, photosynthesis and finally oil synthesis. Similar results have been found by Arancon et al. (2007). Liu et al. (2004) has reported that organic fertilizers increase seed oil percentage through extending seed filling period and increasing leaf area duration. The results revealed that the minimum oil percentage was related to chemical treatment in which urea was individually applied. Under mild and severe drought stress, the maximum oil percentage was obtained from treatments in which more zeolite was applied i.e. zeocompost, Z-ACM and zeocompost + Z-ACM (Fig. 5). It has been reported that zeolite improves water retention capacity and provides more water for the plants (Gholamhoseini et al., 2013). 


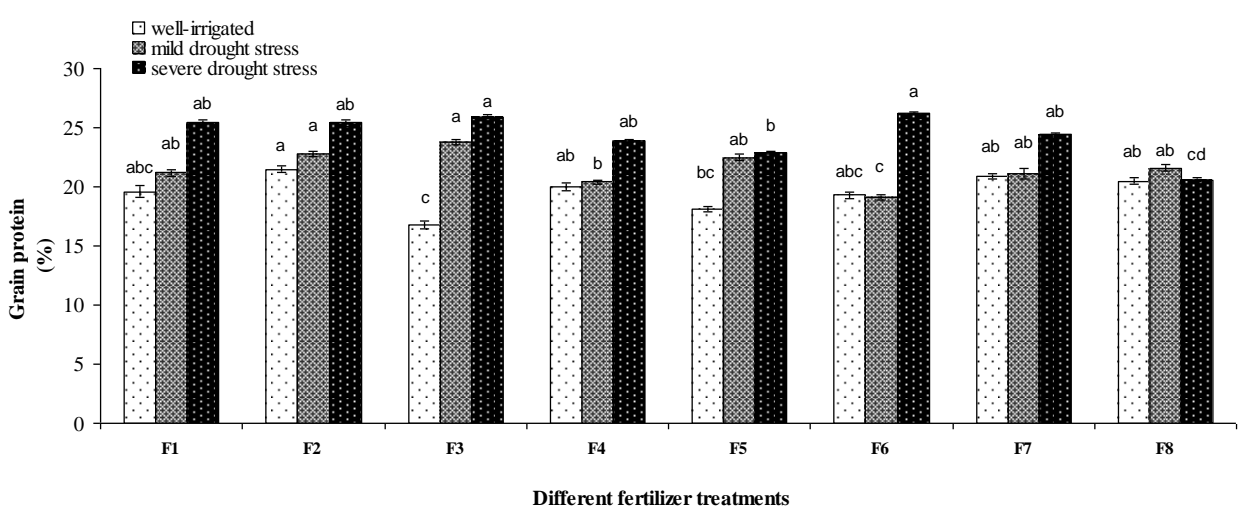

Figure 4: Interaction effect of irrigation treatments $\times$ fertilizer treatments on sunflower grain protein content. In each irrigation treatments, means followed by the same letter are not significantly different $(\mathrm{P} \leq 0.05)$. Vertical bars indicate standard deviation $(\mathrm{n}=3)$

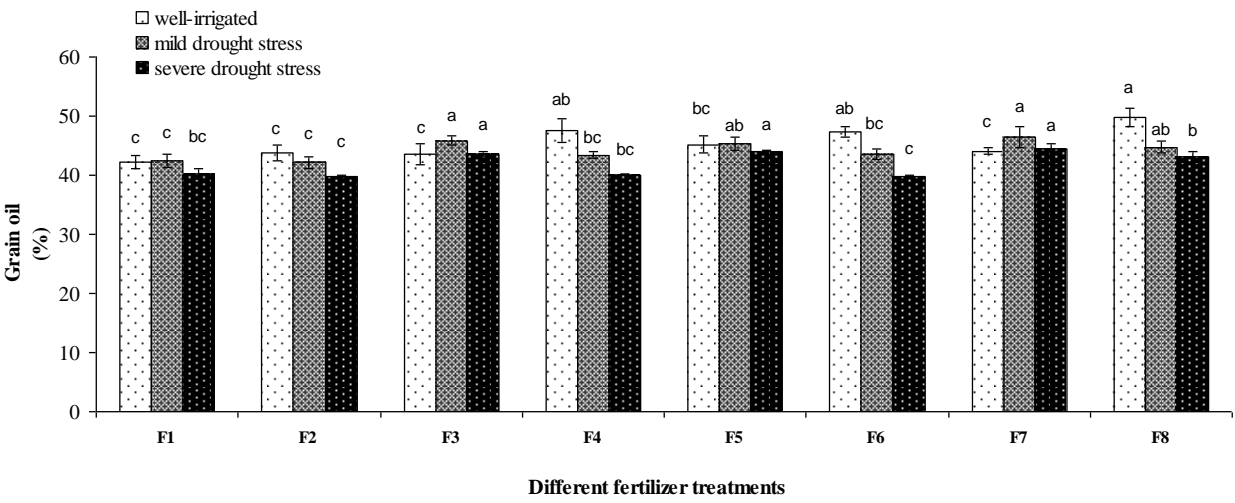

Figure 5: Interaction effect of irrigation treatments $\times$ fertilizer treatments on sunflower grain oil content. In each irrigation treatments, means followed by the same letter are not significantly different $(\mathrm{P} \leq 0.05)$. Vertical bars indicate standard deviation $(\mathrm{n}=3)$

\section{CONCLUSIONS}

This study compared the effects of different irrigation regimes associated with different fertilizer treatments under semiarid climatic conditions on various aspects of sunflower production. The results herein clearly indicate that the application of combined organic fertilizers with 1600-2200 $\mathrm{kg} \mathrm{ha}^{-1}$ zeolite, F6 and F8 treatments, was considerably more effective than the chemical treatment $(\mathrm{F} 1)$ or the integrated treatment without zeolite (F2) for improving most quantitative and qualitative sunflower traits. According to the obtained results, combined organic fertilizers, especially zeocompost + vermicompost, zeocompost $+\mathrm{Z}$-ACM or vermicompost $+\mathrm{Z}-\mathrm{ACM}$, are recommended to use under wellirrigation conditions in sunflower production. Moreover, under drought stress conditions, application of zeolite amended organic fertilizers is highly recommended. Overall we concluded that soil amending with combined organic fertilizers and zeolite can be a beneficial approach for decreasing chemical fertilizer application rates and improving the sustainability of agricultural systems. 


\section{REFERENCES}

Al-Busaidi, A., Yamamoto, T., Inoue, M., Eneji, A. E., Mori, Y., Irshad, M. (2008). Effects of zeolite on soil nutrients and growth of barley following irrigation with saline water. Journal of Plant Nutrition, $\quad 31, \quad 1159-1173$. doi:10.1080/01904160802134434

Allen, R.G., Raes, L.S., Smith, D.M. (1998). Crop Evaportranspiration: Guidelines for Computing Crop Water Requirements. Irrigation and Drainage Paper 56. Food and Agriculture Organization of the United Nations, Rome, p. 300.

Arancon, N.Q., Edwards, C.A., Dick, R., Dick, L. (2007). Vermicompost tea production and plant growth impacts. Biocycle, 48, 51-52.

Baerlocher, C.h., Meier, W.M., Olson, D.H. (2001). Atlas of Zeolite Framework Types. Fifth Revised Editon. Published on behalf of the Structure Commission of the International Zeolite Association by Elsevier., p. 299.

Bandyopadhyay, K.K., Misra, A.K., Ghosh, P.K., Hati, K.M. (2010). Effect of integrated use of farmyard manure and chemical fertilizers on soil physical properties and productivity of soybean. Soil and Tillage Research, 110, 115-125. doi:10.1016/j.still.2010.07.007

Basso, B., Ritchie, J.T. (2005). Impact of compost, manure and inorganic fertilizer on nitrate leaching and yield for a 6-year maize-alfalfa rotation in Michigan. Agriculture, Ecosystems and Environment, 180, 329-341. doi:10.1016/j.agee.2005.01.011

Bigelow, C.A., Bowman, D.C., Cassel, D.K., Rufty, T.W. (2001). Creeping bentgrass response to inorganic soil amendments and mechanically induced subsurface drainage and aeration. Crop Science 41, 797- 805. doi:10.2135/cropsci2001.413797x

Bigelow, C.A., Bowman, D.C., Cassel, D.K. (2004). Physical properties of three sand size classes amended with inorganic materials of sphagnum peat moss for putting green root zones. Crop Science, $\quad 44, \quad 900-907$. doi:10.2135/cropsci2004.9000

D’Andria, R., Chiarnada, V.M., Mori, M. (1995). Yield and soil water uptake of sunflower sown in spring and summer. Agronomy Journal 87, 1122-1128. doi:10.2134/agronj1995.00021962008700060014x

Delate, K., Cambardella, C.A. (2004). Agroecosystem performance during transition to certified organic grain production. Agronomy Journa,. 96, 12881298. doi:10.2134/agronj2004.1288

Edmeades, D.C. (2003). The long-term effects of manures and fertilizers on soil productivity and quality: a review. Nutrient Cycling Agroecosystems, 66, 165-180. doi:10.1023/A:1023999816690

Efeoğlu, B., Ekmekci, Y., Cicek, N. (2008). Physiological responses of three maize cultivars to drought stress and recovery. South African Journal of Botany, 75(1), 34-42. doi:10.1016/j.sajb.2008.06.005

Evanylo, G., Sherony, C., Spargo, J., Starner, D., Brosius, M., Haering, K. (2008). Soil and water environmental effects of fertilizer, manure, and compost based fertility practices in an organic vegetable cropping system. Agriculture, Ecosystems and Environment, 127, 50-58. doi:10.1016/j.agee.2008.02.014

Gholamhoseini, M., Aghaalikhani, M., Dolatabadian, A., Joghan, A.K., Zakikhani, H. (2012). Decreasing $\mathrm{N}$ leaching and increasing canola forage yield in a sandy soil by application of natural zeolite. Agronomy Journal, 104, 1467-1475. doi:10.2134/agronj2012.0145

Gholamhoseini, M., Ghalavand, A., Khodaei-Joghan, A., Dolatabadian, A., Zakikhani, H., Farmanbar, E. (2013). Zeolite-amended cattle manure effects on sunflower yield, seed quality, water use efficiency and nutrient leaching. Soil and Tillage Research, 126, 193-202. doi:10.1016/j.still.2012.08.002

Gholizadeh-Sarabi, S., Sepaskhah, A.R. (2013). Effect of zeolite and saline water application on saturated hydraulic conductivity and infiltration in different soil textures. Archives of Agronomy and Soil Science, 59(5), 753-764. doi:10.1080/03650340.2012.675626

Hay, R., Porter, J. (2006). The Physiology of Crop Yield, Blackwell Publishing, New Jersy, USA.

He, Z.L., Calvert, D.V., Alva, A.K., Li, Y.C., Banks, D.J. (2002). Clinoptilolite Zeolite and cellulose amendments to reduce ammonia volatilization in a calcareous sandy soil. Journal of Plant and Soil, 247, 253-260. doi:10.1023/A:1021584300322

Hermanson, R.W., Pan, C., Perillo, R., Stevans, R., Stockle, C. (2000). Nitrogen use by crop and the fate of nitrogen in the soil and vadose zone. Washington State University and Washington Department of Ecology, Interagency Agreement No. C 9600177. 
Javaad, S., Panwar, A. (2013). Effect of biofertilizer, vermicompost and chemical fertilizer on different biochemical parameters of Glycine max and Vigna mungo. Recent Research in Science and Technology, 5(1), 40-44.

Jing, H., Ridoutt, B.G., Chang-chun, X., Hai-lin, Z., Fu, C. (2012). Cropping pattern modifications change water resource demands in the Beijing metropolitan area. Journal of Integrative Agriculture, 11, 19141923. doi:10.1016/S2095-3119(12)60197-X

Kazi, B.R., Oad, F.C., Jamro, G.H., Jamali, L.A., Oad, N.L. (2002). Effect of water stress on the growth, yield and oil content of sunflower. Pakistan Journal of Applied Sciences, 2(5), 550-552. doi:10.3923/jas.2002.550.552

Khaliq, A., Cheema, Z.A. (2005). Influence of irrigation and nitrogen management on some agronomic traits and yield of hybrid sunflower (Helianthus annuus L.). International Journal of Agriculture and Biology, 7, 915-919.

Leggo, P.J. 2000. An investigation of plant growth in an organo-Zeolite substrate and its ecological significant. Journal of Plant and Soil, 219, 135146. doi:10.1023/A:1004744612234

Leggo, P.J., Ledésert, B., Graham, C. (2006). The role of clinoptilolite in organo-zeolitic-soil systems used for phytoremediation. Science of the Total Environment, 363, 1-10. doi:10.1016/j.scitotenv.2005.09.055

Liu, X., Herbert, S.J., Jin, J., Zhang, Q., Wang, G. (2004). Responses of photosynthesis rates and yield/quality of main crops to irrigation and manure application in the black soil area of Northeast. Plant and Soil, 261, 55-60. doi:10.1023/B:PLSO.0000035553.53865.ec

Mahabadi, A. A., Hajabbasi, M., Khademi, H., Kazemian, H. (2007). Soil cadmium stabilization using an Iranian natural zeolite. Geoderma, 137(3), 388-393. doi:10.1016/j.geoderma.2006.08.032

Miralles, O.M., Valero, J.A., Olalla, F.M. (1997). Growth, development and yield of five sunflower hybrids. European Journal of Agronomy, 6, 47-59. doi:10.1016/S1161-0301(96)02035-7

Nakhli, S.A. A., Delkash, M., Ebrazi Bakhshayesh, B., Kazemian, H. (2017). Application of Zeolites for Sustainable Agriculture: a Review on Water and Nutrient Retention. Water, Air, \& Soil Pollution, 228, 464-496. doi:10.1007/s11270-017-3649-1

Ogbonnaya, C.I., Sarr, B., Brou, C., Diouf, O., Diop, N., Macauley, H.R., (2003). Selection of cowpea genotypes in hydroponics, pots, and field for drought tolerance. Crop Science 43, 111-112. doi:10.2135/cropsci2003.1114

Ramesh, K., Damodar Reddy, D., Kumar Biswas, A., Subba Rao, A. (2011). Zeolites and their potential uses in agriculture. Advances in Agronomy, 113, 219-241. doi:10.1016/B978-0-12-386473-4.00004$\mathrm{X}$

Razmi, Z., Sepaskhah, A.R. (2012). Effect of zeolite on saturated hydraulic conductivity and crack behavior of silty clay paddled soil. Archives of Agronomy and Soil Science, 58(7), 805-816. doi:10.1080/03650340.2010.544653

Rokhzadi, A., Toashih, V. (2011). Nutrient uptake and yield chickpea (Cicer arietinum L.) inoculated with plant growth-promoting rhizobacteria. Australian Journal of Crop Science, 5, 44-48.

Sabahi, H. (2007). The effects of integrated application of organic and inorganic fertilizers on physico chemical and biological properties of soil and yield of canola (Brassica napus) at Zirab region (Sary). Ph.D Thesis. Agronomy Department, Agriculture Faculty, Tarbiat Modares University, p.102.

Salehi, A., Tasdighi, H., Gholamhoseini, M. (2016). Evaluation of proline, chlorophyll, soluble sugar content and uptake of nutrients in the German chamomile (Matricaria chamomilla L.) under drought stress and organic fertilizer treatments. Asian Pacific Journal of Tropical Biomedicine, 6(10), 886-891. doi:10.1016/j.apjtb.2016.08.009

Sezen, S.M., Yazar, A., Kapur, B., Tekin, S. (2011). Comparison of drip and sprinkler irrigation strategies on sunflower seed and oil yield and quality under Mediterranean climatic conditions. Agriculture Water Management, 98(7), 11531161. doi:10.1016/j.agwat.2011.02.005

Simsek-Ersahin, Y. (2011). The Use of Vermicompost Products to Control Plant Diseases and Pests. In: Karaca A (ed) Biology of Earthworms, Soil Biology Springer-Verlag Berlin Heidelberg doi:10.1007/978-3-642-14636-7_12

Singh, B.K., Pathak, K.A., Verma, A.K., Verma, V.K., Deka B.C. (2011). Effects Of vermicompost, fertilizer and mulch on plant Growth, nodulation and pod yield of French bean (Phaseolus vulgaris L.). Vegetable Crops Research Bulletin, 74(1), 153165. doi:10.2478/v10032-011-0013-7

Soil and Plant Analysis Council. (1999). Soil analysis handbook of reference methods. CRC Press, Boca Raton, FL.

Tarantino, E., Alba, E. (1978). Influence of irrigation and plant density on yield characteristics of some commercial and improved sunflower cultivars 
grown as a second crop. Italian Journal of Agronomy, 12(3), 136-142.

Tarkalson, D.D., Payero, J.O., Ensley, S.M., Shapiro, C.A. (2006). Nitrate accumulation and movement under deficit irrigation in soil receiving cattle manure and commercial fertilizer. Agricultural Water Management, 85, 201-210. doi:10.1016/j.agwat.2006.04.005

Wang, W., Vinocur, B., Altman, A. (2003). Plant responses to drought, salinity and extreme temperatures: Towards genetic engineering for stress tolerance. Planta, 218, 1-14. doi:10.1007/s00425-003-1105-5
Xiubin, H., Zhanbin, H. (2001). Zeolite application for enhancing infiltration and retention in loess soil. Resource, Conservation and Recycling, 34, 45-52. doi:10.1016/S0921-3449(01)00094-5

Yang, L., Zhao, F., Chang, Q., Li, T., Li, F. (2015). Effects of vermicomposts on tomato yield and quality and soil fertility in greenhouse under different soil water regimes. Agriculture Water Management, $\quad 160, \quad 98-105$. doi:10.1016/j.agwat.2015.07.002

Yolcu, H. 2010. Effects of biologic fertilizers on some morphologic properties and yield of Hungarian vetch. Turkey I. Organic Animal Congress, 1-4 July 2010. Kelkit, Turkey, pp 249-253. 